\title{
Reassessing Particulate Organic Carbon Dynamics in the Highly Disturbed San Francisco Bay Estuary
}

\author{
Peter J. Hernes ${ }^{1 *}$, Rachael Y. Dyda ${ }^{1}$ and Brian A. Bergamaschi ${ }^{2}$ \\ ${ }^{1}$ Department of Land, Air, and Water Resources, University of California, Davis, Davis, CA, United States, ${ }^{2}$ U.S. Geological \\ Survey, Sacramento, CA, United States
}

\section{OPEN ACCESS}

Edited by:

Francien Peterse,

Utrecht University, Netherlands

Reviewed by:

Ying $W u$,

East China Normal University, China Elizabeth Ann Canuel, College of William \& Mary,

United States

*Correspondence:

Peter J. Hernes

pjhernes@ucdavis.edu

Specialty section:

This article was submitted to Biogeoscience,

a section of the journal

Frontiers in Earth Science

Received: 26 November 2019

Accepted: 08 May 2020

Published: 16 June 2020

Citation:

Hernes PJ, Dyda RY and Bergamaschi BA (2020) Reassessing Particulate Organic Carbon Dynamics in the Highly Disturbed San Francisco Bay Estuary. Front. Earth Sci. 8:185. doi: 10.3389/feart.2020.00185
Environmental research has been shifting toward a new normal in which a primary focus is to capture change that may be accelerating. In this study, we collected particulate samples in the northern San Francisco Bay Estuary (SFBE) in the fall of 2011 through the spring of 2012 in order to assess vascular plant contributions across both time and space and to compare our findings with a similar set of samples from 1990 to 1992. Across the $\sim 20$-year span, we detected (1) decreasing C: $\mathrm{N}_{a}$ ratios (averages $\pm \mathrm{SD}$ of $12.5 \pm 2.5$ vs. $8.8 \pm 1.4$, significant $t$-test with $p<0.0001$ ); (2) distinct shifts in chlorophyll vs. salinity, with higher chlorophyll concentrations shifting toward freshwater; and (3) greater relative proportions of vascular plant carbon that also appears less degraded (as indicated by lignin measurements) shifting from freshwater toward higher salinities. Lignin compositional data (syringyl:vanillyl and cinnamyl:vanillyl) suggest that increased lignin content in the more saline samples could be derived from wetland materials, while a two-endmember mixing model indicates that a significant portion of the particulate organic carbon (POC) in the western sites (50-60\% as an upper bound, $13-15 \%$ as a lower bound) could be wetland-derived. This has potential implications for the lower food web, given recent work that demonstrates selective feeding by copepods on wetland detrital material in the northern SFBE. The latter has ramifications for proposed wetland restoration within the SFBE and Sacramento River/San Joaquin River Delta system, namely, that restored wetlands could confer important benefits toward the food web. Equally important is to prioritize continued monitoring of particulate organic matter cycling in the SFBE system to make sure that changing conditions are accounted for in any management decision.

Keywords: lignin biomarkers, non-algal particulate organic carbon (POC), chlorophyll, wetland detrital material, particulate organic matter (POM), temperate estuaries, foodweb alterations

\section{INTRODUCTION}

Estuaries are arguably the most challenging environment in which to study water column particulate organic matter (POM), with a diverse array of sources, a multitude of processes that can either produce or mineralize organic matter $(\mathrm{OM})$ in particles, and the potential for complicated flows (both tidal flows and seasonal river flows) that lead to constant settling and resuspension along with widely varying residence times. Anthropogenic activities adjacent to and within estuaries only exacerbate the dynamic range of POM concentrations and compositions at any given time and location. While there is some expectation that change will happen gradually within these systems, 
there are any number of drivers (e.g., invasive species, changing nutrient inputs, and extended drought) that can induce a rapid change in POM dynamics, which then has strong repercussions for the food web.

The San Francisco Bay Estuary (SFBE)-inclusive of the Sacramento River/San Joaquin River Delta-is one example of a system that has undergone frequent and significant perturbations, culminating in native fish populations in serious decline as the ultimate indicator of an overwritten ecosystem. While there are many possible factors in pelagic organism decline (POD), changing amounts and types of food available in the lower food web will always be a cause for concern. In the SFBE, for example, invasive filter feeders (e.g., Potamocorbula amurensis) have significantly reduced the availability of particulate organic carbon (POC) that can support fish (Cohen and Carlton, 1998). The food web in the SFBE has been thought to be dominated by algal particles (Müller-Solger et al., 2002), which is problematic, given that phytoplankton primary production in the SFBE is ranked in the lowest $15 \%$ of the world's estuaries (Cloern et al., 2014). However, recent findings that calanoid copepods in the SFBE preferentially consume wetland detrital materials and can significantly enhance their survival by a combined algal/wetland diet (Harfmann et al., 2019) suggest that proposed wetland remediation within the SFBE system (targets in excess of 40,000 ha; San Francisco Bay Area Wetlands Ecosystem Goals Project, 2015) could confer significant benefits to the lower food web. Hence, it is paramount to better understand the sources and seasonal/spatial distribution of wetland detrital materials within the SFBE.

An ideal means for characterizing sources of POM is to use biomarker measurements that can distinguish between vascular plant materials and algal sources. Lignin, for example, is uniquely produced by vascular plants, and carbon-normalized yields can be used to constrain the proportion of POM derived from a vascular plant source, with the assumption that the remainder is algal/microbial. In one survey of US rivers, for example, carbon-normalized yields of lignin in POM varied from 0.45 to $3.16 \mathrm{mg} 100 \mathrm{mgOC}^{-1}$, with an average of $1.33 \mathrm{mg} 100 \mathrm{mgOC}^{-1}$ (Onstad et al., 2000). This compares to plant materials that can range from 4 to $>20 \mathrm{mg} 100 \mathrm{mgOC}^{-1}$ for woody tissues

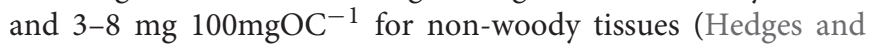
Mann, 1979), but studies that have evaluated POM sources in the Mississippi River, for example, estimate that about half is from vascular plants (Kendall et al., 2001). With a typical C-normalized yield of $\sim 1 \mathrm{mg} 100 \mathrm{mgOC}^{-1}$ for Mississippi POM, this suggests that an appropriate vascular plant endmember for the Mississippi River is on the order of $2 \mathrm{mg} 100 \mathrm{mgOC}^{-1}$. This in turn further indicates that there are other mechanisms for generating POM than simply washing bits of plant material into streams and rivers. In fact, mineral-bound OM typically undergoes at least two phase changes, as first $\mathrm{OM}$ is leached or solubilized from plant materials, and then that solubilized material is sorbed onto minerals, with attendant lignin compositional changes at each step. One laboratory study that mimicked these two phase changes in sequence demonstrated consistently lower $\mathrm{C}$-normalized lignin yields in the resulting mineral-bound OM compared to the parent plant tissues (Hernes et al., 2007).
The total compositional shift is dependent on multiple factors, including the plant type, the mineral type, and the concentration of lignin in the dissolved organic matter (DOM) that contacts mineral surfaces. In any case, establishing an endmember C-normalized lignin yield for a system can provide a powerful tool for estimating sources to POM within that system.

In this study, we conducted a survey of lignin associated with POM within the SFBE from riverine to mid salinity samples across several months to address the general question as to when and where vascular plant sources and concentrations are at their highest, which in turn addresses the issue of where the lower food web is most likely to be supplemented by vascular plant sources. In addition to lignin measurements, our study also included select chlorophyll measurements as an indicator of algal sources, as well as bulk $\mathrm{C}$ and $\mathrm{N}$ measurements that can also be used as a proxy for source estimates.

\section{MATERIALS AND METHODS}

\section{The San Francisco Bay Estuarine System}

The SFBE encompasses the Sacramento-San Joaquin River Delta (the Delta) to the east with seasonal freshwater to oligohaline conditions, all the way out through San Francisco Bay to the Golden Gate with its full marine salinities. The Delta consists of $\sim 315,000$ ha, of which $\sim 70 \%$ is agriculture, 6,700 ha is natural wetland, $\sim 9,500$ ha is managed wetland, and $\sim 26,000$ ha is open water (San Francisco Estuary Institute-Aquatic Science Center [SFEI-ASC], 2014). The Delta supplies drinking water via the State Water Project and Central Valley Project to 27 million people, as well as irrigation water for $>1.2$ million ha of farmland. Reclamation of Delta wetland for farming within the Delta has resulted in a $97 \%$ reduction in wetland habitat (San Francisco Estuary Institute-Aquatic Science Center [SFEIASC], 2014). Agricultural island soils are peat-derived and highly susceptible to wind erosion and oxidative degradation as a result of draining the root zone, as well as compaction from farming, resulting in cumulative island subsidence of up to $6 \mathrm{~m}$ below sea level (Deverel and Rojstaczer, 1996). Management of the Delta system is thus driven in often competing directions as various stakeholders attempt to maximize water exports while others are focused on sustaining remaining habitat quality.

The SFBE is in general a particle-starved system, with extensive upstream dams that retain sediments that historically would flow through the Delta, along with island levees that minimize inputs from within the Delta. These restrictions on sediments may be partially offset by the intense agriculture and associated erosion that occurs within the Central Valley along the Sacramento and San Joaquin rivers and their primary tributaries.

This study primarily focused on the northern SFBE in the Delta, which primarily receives its water from the Sacramento River, which drains the eastern slope of the California Coastal Range, the intensively farmed Sacramento Valley, the western slope of the Sierra Nevada, and the southern reaches of the Cascade Range (Jassby and Cloern, 2000). However, tidal flows throughout the study region are always greater than riverine discharge, and previous studies in the SF estuary have shown that 
tidal pumping of particles can transport significant quantities of wetland-derived material into the water column (Bergamaschi et al., 2011; Bergamaschi et al., 2012). The overall volume of the Delta and SFBE is such that water residence times at each station sampled ranged from 1 week to 2 months, depending on inflows (Lucas, 2010).

\section{Sample Collection and Processing}

Water samples were collected approximately monthly from October 2011 to April 2012 in conjunction with the California Department of Fish and Wildlife midwater annual fish trawls (see Figure 1 for station map and Supplementary Figure S1 for sampling periods in relation to Sacramento River discharge). At each station, several liters of water were collected in order to generate a sufficient number of filters for all analyses. Included were at least one tared $0.45-\mu \mathrm{m}$ glass fiber filter (GFF) filter (25 or $47 \mathrm{~mm}$ diameter) for elemental analyses, and three to six tared $0.45-\mu \mathrm{m}$ HAWP membrane filters (47 mm diameter, mixed cellulose esters of acetate and nitrate, MF-Millipore) for particulate lignin. Depending on TSS concentrations, each 47$\mathrm{mm}$ filter could pass through a few hundred milliliters to $1 \mathrm{~L}$ of water before clogging. Chlorophyll samples were collected separately by US Geological Survey (USGS) for analysis by a subcontractor. All filtrations included a light rinse of nanopure water to remove salts. Filters were stored in an ice cooler until transport back to UCDavis (2-6 h), where they were then dried at $50^{\circ} \mathrm{C}$ and weighed. Lignin samples were extracted from the HAWP filters in nanopure water with minimal sonication to dislodge particles, then water was transferred to Monel reaction vessels (Prime Focus, Inc.) and dried under vacuum centrifugation. All filter materials interfere with lignin analyses, hence the need to remove particles. HAWP filters were chosen because they are not fibrous like GFF or cellulose, therefore enabling quantitative removal with $<30 \mathrm{~s}$ of sonication time that is not dependent on particle loading. Greater sonication times begin to release filter material along with the sample, which can also lead to interference.

\section{Particulate Organic Carbon, Particulate Nitrogen, and Total Suspended Sediment Analyses}

Particulate organic carbon and particulate nitrogen (PN) measurements were generated by one of three methods. The 25$\mathrm{mm}$ GFF filters were small enough to analyze in their entirety. Initial analyses of the 47-mm GFF filters were conducted by cutting the filters into thirds and analyzing all three pieces in their entirety and summing them. Subsequently, we opted to use a hole-punch method on the remainder of the 47-mm GFF filters, whereby four to six small $(\sim 6-\mathrm{mm})$ disks were punched from varied locations on each filter and analyzed as one composite, then scaled by area. No significant difference was apparent when using four vs. six disks, and subsequently four holes was used for the remainder of the samples. Filters were folded into tin boats and analyzed on a Costech ECS 4010 analyzer and quantified using acetanilide as a standard. Approximately 15\% of the samples included replication between 25 - and $47-\mathrm{mm}$ filters, and when converted to POC $\left(\mathrm{mg} \mathrm{L}^{-1}\right)$, the replicates varied by $<10 \%$.

Total suspended sediment (TSS) was determined on all HAWP and GFF filters by taring the filters prior to sample loading and weighing them after drying. The mass difference was then normalized to the volume of water filtered.

\section{Biomarker Analyses}

Lignin analyses were carried out by $\mathrm{CuO}$ oxidation following a modified version as summarized by Spencer et al. (2010) and Hernes et al. (2013b). Following oxidation in $8 \% \mathrm{NaOH}$ in the presence of excess $\mathrm{CuO}$ at $155^{\circ} \mathrm{C}$ for $3 \mathrm{~h}$, samples were acidified and extracted three times with ethyl acetate. Excess solvent was blown off under a gentle stream of ultrapure nitrogen. Samples were then stored frozen until analysis. Lignin phenols were trimethylsilyl derivatized using bistrimethylsilyltrifluoromethylacetamide (BSTFA); separation of phenols was achieved using an Agilent 6890 gas chromatograph fitted with a DB5-MS capillary column $(30 \mathrm{~m}, 0.25 \mathrm{~mm}$ inner diameter; J\&W Scientific) and equipped with an Agilent 5973 mass selective detector. Quantification was achieved using selected ion monitoring with cinnamic acid as an internal standard following the five-point calibration scheme of Hernes and Benner (2002). All samples were blank-corrected due to the presence of trace amounts of contamination in the $\mathrm{NaOH}$ reagent. At least one blank was run for every 10 sample oxidations performed. Blank concentrations of lignin phenols were low (15-25 ng) for the eight lignin phenols measured in this study (three vanillyl phenols: vanillin, acetovanillone, vanillic acid; three syringyl phenols: syringaldehyde, acetosyringone, syringic acid; and two cinnamyl phenols: $p$-coumaric acid, ferulic acid). Total blanks for these eight compounds never exceeded $2 \%$ of the sample yields.

Chlorophyll a (Chl-a) was determined using SM10200$\mathrm{H}$ (Clesceri et al., 1998). Briefly, 0.5-1 L of sample was filtered through Whatman GF/F glass fiber filters. Filters were freeze-dried and extracted with $90 \%$ ethanol (an alteration from the standard method, which uses $90 \%$ acetone) prior to quantification by fluorometry. The limit of detection is dependent on filtration volumes, but approximately $0.5 \mu \mathrm{g} \mathrm{L}^{-1}$.

\section{Mixing Model and Statistical Analyses}

A two-endmember linear mixing model with carbon-normalized lignin, $\Lambda_{8}$, was used to calculate potential contributions of wetland material to POC in samples in the western portion of the study region. The background $\Lambda_{8}$ endmember value was represented by the Sacramento River station 711, while wetland materials were represented in two ways: (1) a tule/cattail senescent plant material endmember and (2) a mineral-bound endmember estimated from a Mississippi River dataset (Kendall et al., 2001). For any given sample, a \%wetland component was calculated as follows:

$$
\begin{aligned}
\% \text { Wetland }= & \left(\text { Sample } \Lambda_{8}-\text { Sacramento River } \Lambda_{8}\right) \times 100 \% / \\
& \left(\text { Wetland } \Lambda_{8}-\text { Sacramento River } \Lambda_{8}\right)
\end{aligned}
$$




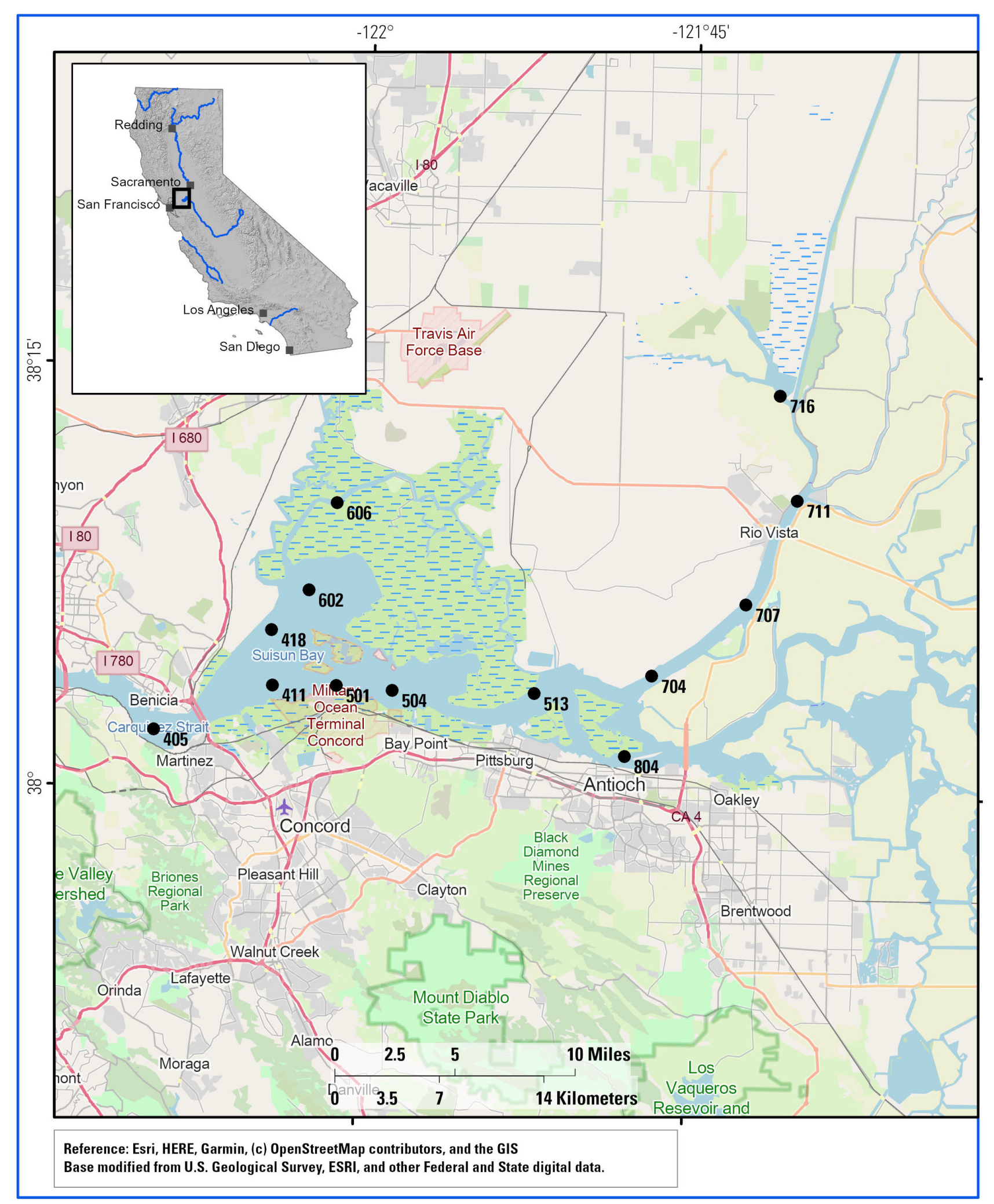

FIGURE 1 | Stations sampled in this study. Green shading with blue dashes indicates wetland areas. Station numbers correspond to the annual Fall Mid Water Trawl conducted by the California Department of Fish and Wildlife. The Sacramento Deep Water Ship Channel extends NNE from station 716 while the mainstem Sacramento River enters the Delta at station 711. 
Linear regression and curve-fitting analyses were conducted using SigmaPlot 11.0 (Systat Software, Inc.). Averages, standard deviations, and two-tailed $t$-tests assuming unequal variance were calculated in Excel.

\section{RESULTS}

\section{Total Suspended Sediment, Salinity, Carbon, and Nitrogen}

Over the 7-month sampling period in 2011-2012, the maximum TSS concentration that was measured was $183 \mathrm{mg} \mathrm{L}^{-1}$, which occurred in April at station 411 in the main channel by Suisun Bay (Figure 1), an area that typically generates higher resuspension due to wind direction and the extent of open water. However, the median TSS across all stations and sampling periods was only $31.9 \mathrm{mg} \mathrm{L}^{-1}$, with a low of only $7.6 \mathrm{mg} \mathrm{L}^{-1}$, also in April, but at station 804, which is off the main flowpath of the Sacramento River.

Salinity across the sites were measured from 0 to 19.1, demonstrating typical estuarine variability. Highest values were most common in November, January, and February.

Particulate organic carbon concentrations were strongly correlated with TSS $\left(r^{2}=0.93, p<0.0001\right)$ and ranged from 0.26 to $3.51 \mathrm{mg} \mathrm{L}^{-1}$ (Supplementary Table S1). The average of $1.02 \mathrm{mg} \mathrm{L}^{-1}$ is approximately one third of historical average values for dissolved organic carbon (DOC) within the open waters and channels of the Delta across time series (e.g., Eckard et al., 2007). Weight percent carbon varied from 1.37 to $6.27 \%$ and generally trended from higher percentages in the eastern, more upstream samples to lower percentages in western, more downstream samples.

Particulate nitrogen concentrations were closely linked to POC $\left(r^{2}=0.96, p<0.0001\right)$ and ranged from 0.05 to $0.39 \mathrm{mg} \mathrm{L}^{-1}$ with an average of $0.13 \mathrm{mg} \mathrm{L}^{-1}$ (Supplementary Table S1). This typically represents $<20 \%$ of the total $\mathrm{N}$ in the water column. Atomic C:N ratios averaged 8.8 (range 5.0-12.4), which is notably higher than that of a pure phytoplankton endmember (Redfield ratio $=6.6)$ but much lower than vascular plant tissues $(\sim 20-100$ for nonwoody tissues, $>100$ for woody tissues).

\section{Lignin and Chlorophyll Biomarkers}

Particulate lignin concentrations ranged from 1.2 to $31.6 \mu \mathrm{g} \mathrm{L}^{-1}$ with an average of $7.2 \mu \mathrm{g} \mathrm{L}^{-1}$ (Supplementary Table S1), which is on the high end of other US rivers $\left(2.5 \mu \mathrm{g} \mathrm{L}^{-1}\right.$ average; Onstad et al., 2000), but low in comparison to tropical rivers (4.5-91.3 $\mu \mathrm{g} \mathrm{L}^{-1}$ ) summarized in Hernes et al. (2017a). The highest concentration in this study was observed at station 405 in April, which had the second highest TSS observed. In general, April particulate lignin concentrations in the western half of the study area were notably higher than all other samples, which reflects the much greater TSS also measured in those samples. The correlation between lignin concentrations and TSS $\left(r^{2}=0.91\right.$, $p<0.0001)$ was similar to that for POC vs. TSS $\left(r^{2}=0.93\right)$. Closing the loop, the correlation between lignin concentration and POC was similarly strong $\left(r^{2}=0.90, p<0.0001\right)$, and this manifests itself in carbon-normalized lignin yields, $\Lambda_{8}$, that ranged from 0.20 to $1.34 \mathrm{mg} 100 \mathrm{mgOC}^{-1}$ and averaged 0.61 , with the standard deviation (0.28) less than half the average. These values are low in comparison to the aforementioned US (average 1.3) and tropical rivers (0.4-3.3) (Onstad et al., 2000; Hernes et al., 2017a). The highest $\Lambda_{8}$ in this study was at station 513 in March, while the lowest was at station 716, also in March, at the southern end of the Sacramento Deepwater Ship Canal (Figure 1 and Supplementary Table S1).

Lignin compositional parameters across the sample set demonstrated similar variability to carbon-normalized yields. The ratio of syringyl to vanillyl phenols, $\mathrm{S}: \mathrm{V}$, varied from 0.04 (indicative of gymnosperms, in the absence of significant diagenetic processing) to 1.29 (indicative of angiosperms) with an average of 0.61 . Several of the lowest values were measured in October and November at multiple stations. All of the highest values were measured in January through March, again at multiple stations. Ratios of cinnamyl to vanillyl phenols, $\mathrm{C}: \mathrm{V}$, ranged from 0.03 (indicative of woody tissues) to 0.87 (indicative of nonwoody tissues, typically monocots) and averaged 0.23 .

Lignin compositions also include the acid to aldehyde diagenetic parameters, which tend to increase with degradation and with any phase changes from solids to liquids (Hernes et al., 2007; Hernes et al., 2013a). Vanillic acid to vanillin, (Ad:Al)v, ranged from 0.53 to 1.27 with an average of 0.78 . (Ad:Al)v for fresh plant tissues are typically less than 0.4 while values $>1$ are typical of mineral-bound lignin sorbed from the dissolved phase. The highest (Ad:Al)v tended to occur in the October and November samples. Syringic acid to syringaldehyde, (Ad:Al)s, was more variable, from 0.21 to 1.61 with an average of 0.41 . For dissolved lignin, (Ad:Al)v and (Ad:Al)s are typically strongly positively correlated; however, in this study of particulate lignin, the correlation, although significant $(p=0.012)$, was weak with an $r^{2}=0.09$.

Across the stations measured for lignin and elemental analyses, Chl-a ranged from 0.5 to $8.8 \mu \mathrm{g} \mathrm{L}^{-1}$ with an average of $2.1 \mu \mathrm{g} \mathrm{L}^{-1}$ (Figure 2A and Supplementary Table S1).

\section{DISCUSSION}

The reemergence of the debate on non-algal particles as a potentially significant contributor to the lower SFBE food web comes 15-25 years after a series of earlier papers examined particle cycling in the SFBE and generally concluded that algal particles were the dominant source of carbon to zooplankton and higher trophic levels. Clearly, the SFBE is net heterotrophic, but the consensus seemed to be that non-algal particles were primarily supporting microbial respiration (Müller-Solger et al., 2002; Sobczak et al., 2005). The recent study by Harfmann et al. (2019) that demonstrates preferential consumption of wetland detrital material by copepods (Eurytemora affinis) and enhanced survival for those same copepods when adding wetland detrital material to algal food sources has opened the possibility that non-algal particles are more important to the lower SFBE food web than previously thought. This new paradigm may not be so much a falsification of the previous studies, but rather an indication 

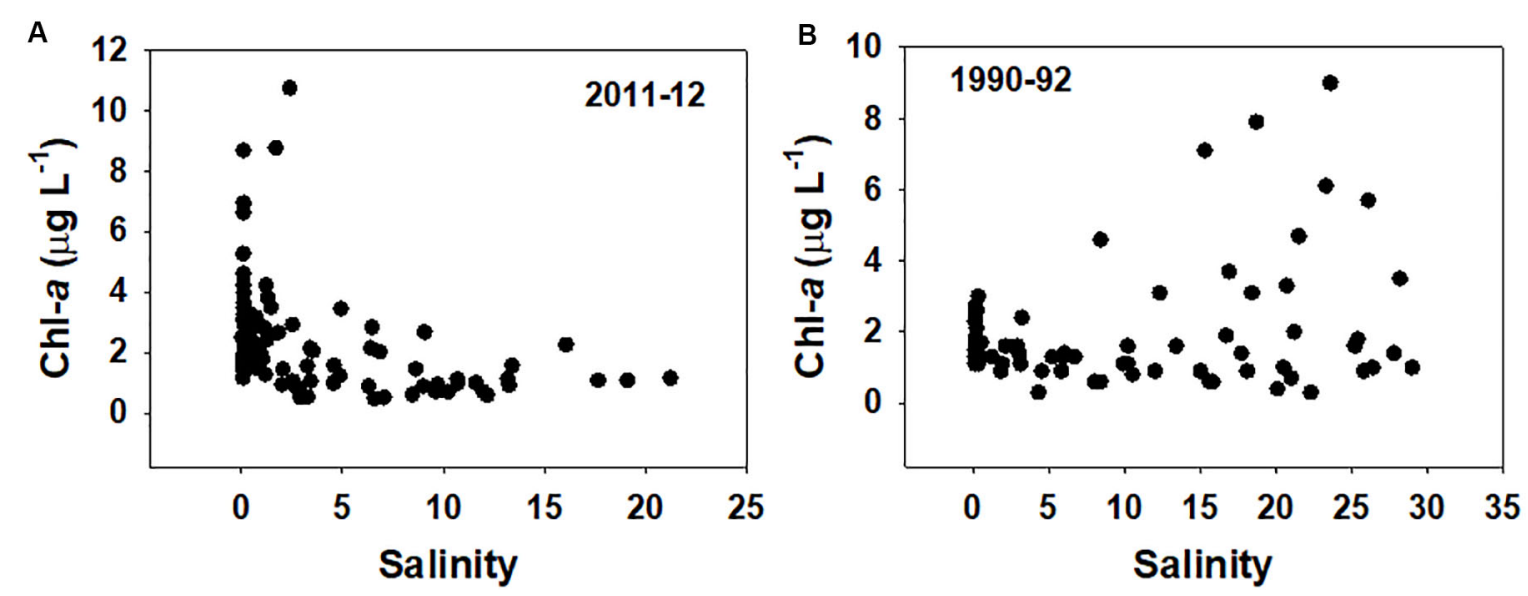

FIGURE 2 | (A) All chlorophyll data from this study plotted vs. salinity for the 2011-2012 water year. (B) Chlorophyll data for northern San Francisco Bay Estuary (SFBE) sites vs. salinity from 1990 to 1992 (Cloern et al., 1993; Canuel et al., 1995).

of changing particle dynamics within the SFBE that have led to adaptation.

\section{Seasonal and Spatial Variability}

The Sacramento River contributes $\sim 85 \%$ of the freshwater flowing into the Delta, and the northern Sierra 8 station precipitation index gives a good representation of year-to-year relative freshwater flows into the Sacramento River. This index measured 1,057 mm for water year 2011-2012 (i.e., October 1, 2011, through September 30, 2012), which was somewhat lower than the median of $1,213 \mathrm{~mm}$, dating back to 1921 . In other words, our sampling regime captured average conditions. That said, there is certainly variability in freshwater inputs throughout the year, and the relationship between our sampling dates and the hydrograph of the Sacramento River are represented in Supplementary Figure S1. The most striking difference among the sampling periods was the higher discharge in the middle of a series of storm systems captured by the April sampling trip. We investigated significant differences (two-tailed $t$-test assuming unequal variances) for a number of key chemical measurements between each of the monthly sampling pairs (Supplementary Table S2). With 200 paired $t$-tests, there is a high probability that $\mathrm{p}$-values hovering around 0.05 are false positives, therefore it is important to look for trends across several pairs and put more stock in $p$-values that are below 0.01 , as even this threshold could lead to two false positives out of 200 . With these caveats to consider, the significant differences between October and all other months for $\mathrm{S}: \mathrm{V}$ ratios are more likely the result of unusual lignin measurements in the October samples as opposed to a real difference. On the other hand, it is clear that the concentrations in April for most measurements are different from all other months. This is primarily represented by lower salinity due to the increased influx of freshwater and the higher TSS concentrations, which then also propagates to higher POC, PN, and particulate lignin concentrations. Notably, the compositional measurements [wt $\%$ OC, $\mathrm{C}: \mathrm{N}_{\mathrm{a}}, \Lambda_{8}, \mathrm{~S}: \mathrm{V}$ other than October, $\mathrm{C}: \mathrm{V},(\mathrm{Ad}: \mathrm{Al}) \mathrm{v}$, and $(\mathrm{Ad}: \mathrm{Al}) \mathrm{s}]$ all indicate a relatively uniform chemistry across the seasons, suggesting that OM sources are similar. The fact that Chl-a concentrations did not stand out in April compared to other months indicates that it is decoupled from background particulate sources and concentrations.

As opposed to relatively benign differences in seasonal parameters, grouping the stations according to western (stations 405 through 606) and eastern (stations 704 through 804) locations led to statistically significant differences (two-tailed $t$-test assuming unequal variances) in all primary measurements (PN p-value slightly greater than 0.05) except for three of the four lignin compositional ratios (Table 1). Western stations on average had higher salinities, TSS, POC, PN, lignin concentrations $\left(\sum_{8}\right), \mathrm{C}: \mathrm{N}_{\mathrm{a}}$, and carbon-normalized lignin yields $\left(\Lambda_{8}\right)$, with lower Chl-a, wt\% OC, \%Phytoplankton-Carbon. This has significant ramifications for both the food quantity and quality for the lower food web, with the eastern locations more enriched in higher quality phytoplankton but the western locations containing higher concentrations overall of POC and non-algal food sources.

\section{North San Francisco Bay Estuary Particulate Organic Carbon Now and} Then

The dataset in this study compares most closely to the study of Canuel et al. (1995) who investigated water column particles (seston) across several sampling conditions in 1990 and 1991 in both the northern and southern SFBE, the former corresponding to the sampling areas from this study. Sampling for that study actually extended into 1992, and the longer dataset is accessible in a USGS Open-File report by Cloern et al. (1993). Notably, annual precipitation at the northern Sierra 8 station index in these water years was comparable but slightly lower than for 2011-2012, by approximately $125 \mathrm{~mm}$. Across several different measurements, averages for the northern SFBE in 1990-1992 are similar to this study (Table 2), with the singular exception of atomic C:N ratios $\left(\mathrm{C}: \mathrm{N}_{\mathrm{a}}\right)$, which were much higher in 1990-1992 (average $=12.5$, 


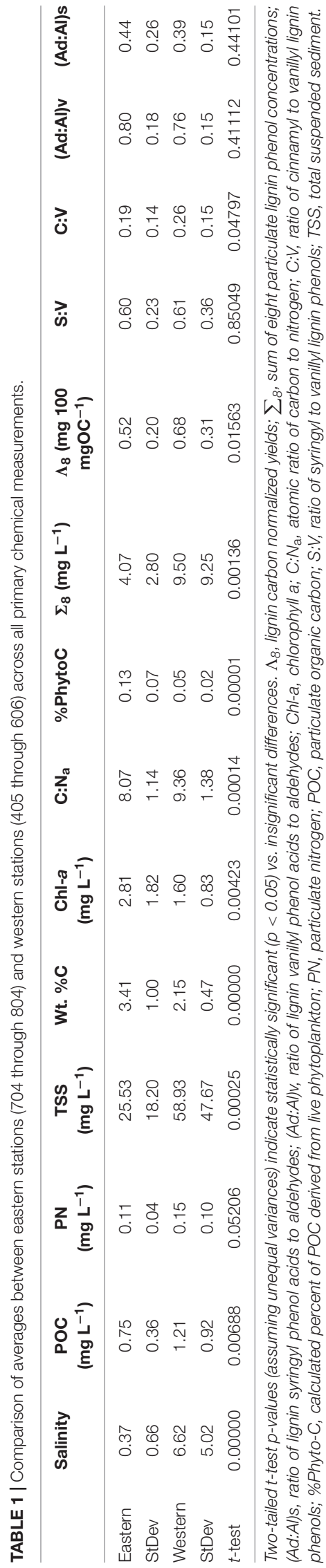

$\mathrm{SD}=2.5$ ) than 20 years later (average $=8.8, \mathrm{SD}=1.4$ ). An even earlier study that sampled the northern SFBE in late September of 1984 also measured higher C:N ratios, ranging from 13 to 16 (SD = 1.7; Sigleo and Macko, 2002). Interestingly, Chesapeake Bay samples in the Sigleo and Macko study within the same 1984 time frame (C: $N_{a}$ from 7 to 12 ) were more similar to our measured values. In contrast, $\mathrm{C}: \mathrm{N}_{\mathrm{a}}$ of particulates measured during low-flow northern SFBE conditions in 1996 averaged $\sim 10.5$ (SD = 3.3; Murrell and Hollibaugh, 2000), hinting at a shift that was already underway. A more extensive suite of freshwater (salinity <2) northern SFBE samples from 1998 to 2000 suggests a continuing shift, with C: $\mathrm{N}_{\mathrm{a}}$ averages of $9.6(\mathrm{SD}=2.1)$ across 10 sampling events, and $10.2(S D=2.0)$ excluding two July samplings to more closely match the sampling dates in this study (Cloern et al., 2002). (Supplementary Figure S2 provides a graphical representation of shifting $\mathrm{C}: \mathrm{N}_{\mathrm{a}}$.) Interestingly, whereas the Cloern et al. (2002) study generated July C: $\mathrm{N}_{\mathrm{a}}$ that was significantly lower than the rest of the year, July C: $\mathrm{N}_{\mathrm{a}}$ from the Canuel et al. (1995) study was indistinguishable from other sampling periods.

Higher $\mathrm{C}: \mathrm{N}_{\mathrm{a}}$ ratios are typically associated with contributions from terrigenous plants, as well as lower food quality. However, similar chlorophyll content and POC concentrations between the 1990-1992 dataset and this dataset indicate that C: $\mathrm{N}_{\mathrm{a}}$ changes are not due to changes in phytoplankton. And while the high C: $N_{a}$ ratios from 1990 to 1992 may be consistent with greater proportions of vascular plants, this is not supported by chemical measurements, as both $\delta{ }^{13} \mathrm{C}$ values and higher plant lipids from 1990 to 1992 and lignin data from this study indicate similarly low contributions from vascular plants. One potential explanation for the much lower $\mathrm{C}: \mathrm{N}_{\mathrm{a}}$ ratios in the current study could be a significant increase in the contribution of inorganic nitrogen to Delta particles. However, methodology for separating organic from inorganic nitrogen on particles makes this challenging to evaluate. An alternative explanation could be greater contributions from microbially derived OM, with typical C: $\mathrm{N}_{\mathrm{a}}$ ratios of $\sim 4$. However, no comparative data exist between the two studies to support or falsify this hypothesis. A key factor to consider is that living microbes on particles are a trivial $(<<1 \%)$ component of the POM, and therefore any significant changes in microbial contributions would have to be from nonliving detritus or sorbed exudates. In any case, lower C: $\mathrm{N}_{\mathrm{a}}$ values could imply higher food quality that allows for greater utilization by copepods in the current Delta as compared to studies in the late 1990s.

As would be expected across any salinity gradient, both studies revealed chemical gradients as well. Across all seasons, chlorophyll concentrations in 1990-1992 trended higher in the more saline samples (westernmost) (Figure 2B). As already indicated, our study revealed an interesting contrast, as the highest chlorophyll concentrations in 2011-2012 were consistently in the eastern freshwater samples rather than in the western saline samples (Table 1 and Figure 2A). Chlorophyll concentrations and primary production in general in the Delta have experienced major changes, including significant reductions in the late 1980s (e.g., Dahm et al., 2016) just prior to the two studies compared here. In other words, primary production and 
TABLE 2 | Select averages compared between two studies 20 years apart.

\begin{tabular}{|c|c|c|c|c|c|c|}
\hline & $\mathrm{POC}\left(\mathrm{mg} \mathrm{L}^{-1}\right)$ & $\begin{array}{c}\text { Chl-a } \\
\left(\mathrm{mg} \mathrm{L}^{-1}\right)\end{array}$ & TSS (mg L $\left.{ }^{-1}\right)$ & Wt\% OC & \%Phyto-C & $\mathrm{C}: \mathrm{N}_{\mathrm{a}}$ \\
\hline 1990-1992 & 0.97 & 1.93 & 37.8 & 2.69 & $10.7 \%$ & 12.5 \\
\hline StdDev & 0.84 & 1.71 & 30.1 & 1.37 & $9.6 \%$ & 2.5 \\
\hline 2011-2012 & 1.02 & 2.13 & 44.8 & 2.69 & $8.9 \%$ & 8.8 \\
\hline StdDev & 0.77 & 1.47 & 41.3 & 0.97 & $6.5 \%$ & 1.4 \\
\hline$t$-test & $\begin{array}{l}\text { rejected } \\
p>0.05\end{array}$ & $\begin{array}{l}\text { rejected } \\
p>0.05\end{array}$ & $\begin{array}{c}\text { rejected } \\
p>0.05\end{array}$ & $\begin{array}{l}\text { rejected } \\
p>0.05\end{array}$ & $\begin{array}{l}\text { rejected } \\
p>0.05\end{array}$ & $\begin{array}{c}\text { significant } \\
p<0.0001\end{array}$ \\
\hline
\end{tabular}

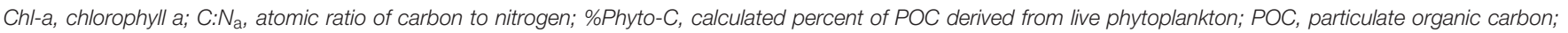

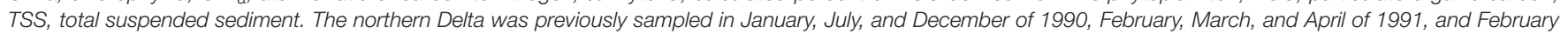
of 1992 for a total of 75 samples (Canuel et al., 1995). However, only Chl-a and TSS were measured in the nine samples from February 1991.

chlorophyll concentrations across the $\sim 20$ years compared here have been fairly similar, but these results suggest that primary production has continued to evolve spatially. Also of note is that soon after our samples were collected in 2011-2012, primary production in the Delta appears to have shifted away from a diatom-dominated system to a cyanobacteria-dominated system (e.g., Kurobe et al., 2018), further emphasizing the continuously changing nature of carbon cycling in the Delta. In any case, if the spatial shift in primary production does indeed represent a new dynamic within the SFBE, then it could signal a greater reliance for the lower food web in the western Delta on non-algal POM such as wetland detrital material moving forward.

In concert with the changing patterns in primary productivity, a comparison of higher plants across the salinity gradient reveals yet another indicator as to changing food web dynamics in the SFBE. Whereas the 1990-1992 sample set revealed higher $\mathrm{C}: \mathrm{N}_{\mathrm{a}}$, greater relative proportions of higher plant lipids, and more depleted ${ }^{13} \mathrm{C}$ in the freshwater (easternmost) samples-all indicative of greater vascular plant contributions to POM in freshwater-the 2011-2012 sample set yielded consistently higher carbon-normalized yields of lignin, $\Lambda_{8}$, in the westernmost higher salinity samples than the easternmost freshwater samples (Table 1 and Figure 3, every month trends higher with higher salinity except November). In other words, the proportion of POM that is derived from vascular plants appears to have reversed itself across the salinity gradient such that there is now more vascular plant POM available in the western saline samples than in 1990-1992. Further, the ratio of acid to aldehyde for vanillyl phenols, $(\mathrm{Ad}: \mathrm{Al}) \mathrm{v}$, indicates that the greater amounts of vascular plant material in the western samples is also fresher (Figure 4), which could make it a more viable food supplement for the lower food web when not enough algal material is present.

\section{Comparison With Other Rivers/Estuaries}

Within the contiguous United States, there are a number of studies that include lignin measurements on riverine particulates. The broadest survey included 17 sites within the central US, with samples from the Colorado, Illinois, Missouri, Ohio, Mississippi, and Rio Grande rivers, among others (Onstad et al., 2000). Within California, the Eel River has been characterized seasonally, along with the similar Umpqua River in Oregon (Goñi et al., 2013). Within a single system with similar vegetation throughout, C: $\mathrm{N}_{\mathrm{a}}$

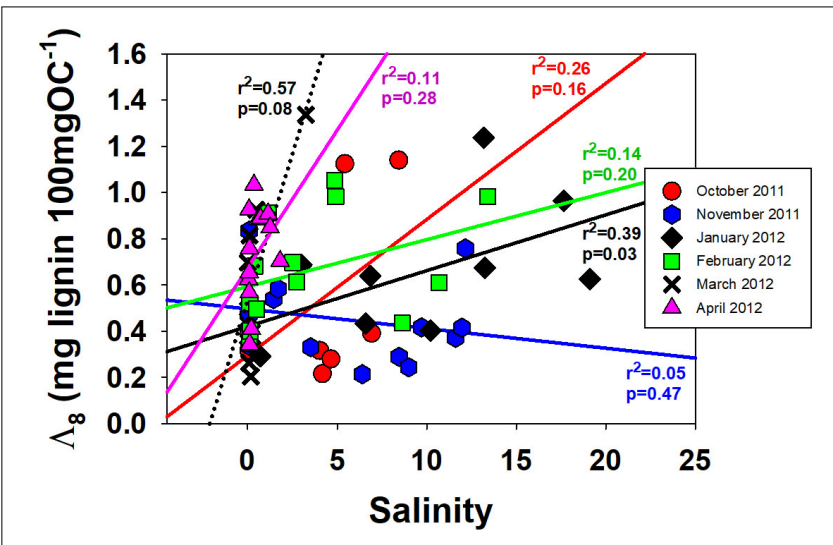

FIGURE 3 | Carbon-normalized lignin yields, $\Lambda_{8}$, vs. salinity for each of the sampling months. Trend lines are included by each month to demonstrate generally higher values in the western stations, except for November.

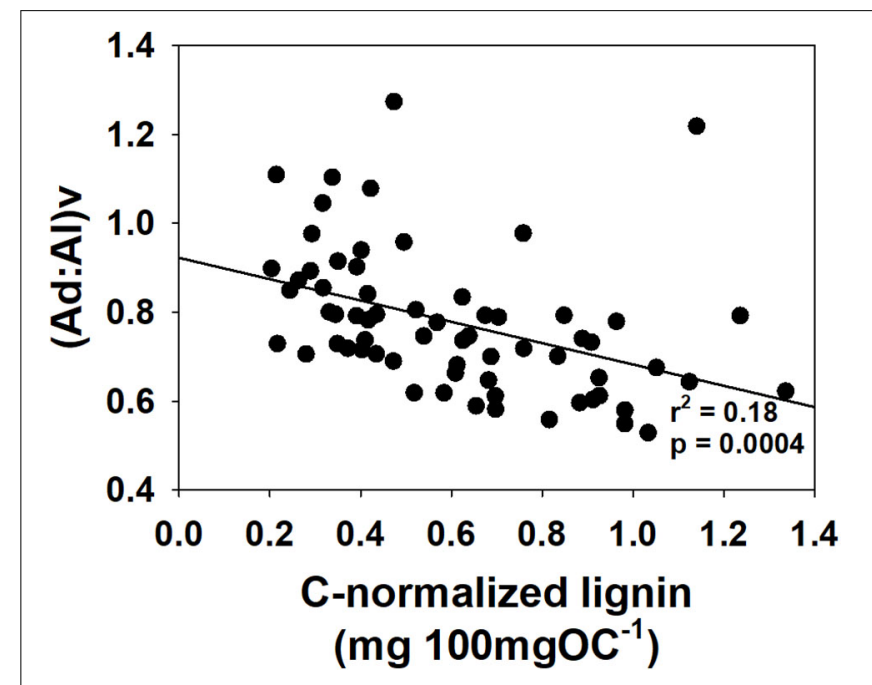

FIGURE 4 | Vanillic acid to vanillin ratios, (Ad:Al)v, vs. carbon-normalized lignin yields, $\Lambda_{8}$, for all data.

can reasonably be expected to correlate to $\Lambda_{8}$, i.e., fresh tissues from vascular plants have high C: $\mathrm{N}_{\mathrm{a}}$ and high lignin content. This is approximated by the Eel and Umpqua data (Figure 5). Across 
multiple systems, this relationship is less likely, as evidenced by the suite of samples from the central US (Figure 5).

There are several striking features of the SFBE samples in the same $\Lambda_{8}$ vs. C: $\mathrm{N}_{\mathrm{a}}$ space: (1) although some overlap is present between the samples in this study and the central US rivers, the overall vascular plant dynamics in the SFBE watershed are quite different from the other systems; (2) the lack of correlation between $\Lambda_{8}$ and C: $\mathrm{N}_{\mathrm{a}}$ for the SFBE samples is indicative of the complexity/diversity of sources at various points, with riverine headwaters in conifer forests, then flowing through agricultural systems before finally encountering significant wetland inputs within the SFBE Delta; and (3) if the particles from the Eel and Umpqua rivers are representative of mountainous headwater particulate lignin from conifer forests (which could also characterize the headwaters of the rivers feeding the Delta), then Delta samples have undergone considerable transformation as the Sacramento and San Joaquin feeder rivers have passed through agricultural and wetland areas, and this transformation has resulted in POM that might be $<20 \%$ vascular plant derived when comparing the highest $\Lambda_{8}$ of $\sim 5 \mathrm{mg} 100 \mathrm{mgOC}^{-1}$ in the Eel/Umpqua systems and the $\Lambda_{8}$ values of $\sim 1 \mathrm{mg} 100 \mathrm{mgOC}^{-1}$ or lower in this study. The concept of overprinting has previously been demonstrated for DOC in various river/estuarine systems (Eckard et al., 2007; Eckard et al., 2020; Hernes et al., 2017b), this study perhaps demonstrates that the same principle holds true for riverine POC as well.

\section{Lignin Biomarkers as an Indicator of Vascular Plant Food Quality}

While the study of Harfmann et al. (2019) directly demonstrated a role for wetland detrital material in the lower Delta food web via ingestion and increased survival by copepods, a previous isotopic mixing model evaluating fish vs. food sources concluded that isotopically, fish in Delta wetlands appear to derive $\sim 70 \%$ of their biomass from wetland plant materials-presumably via transfer

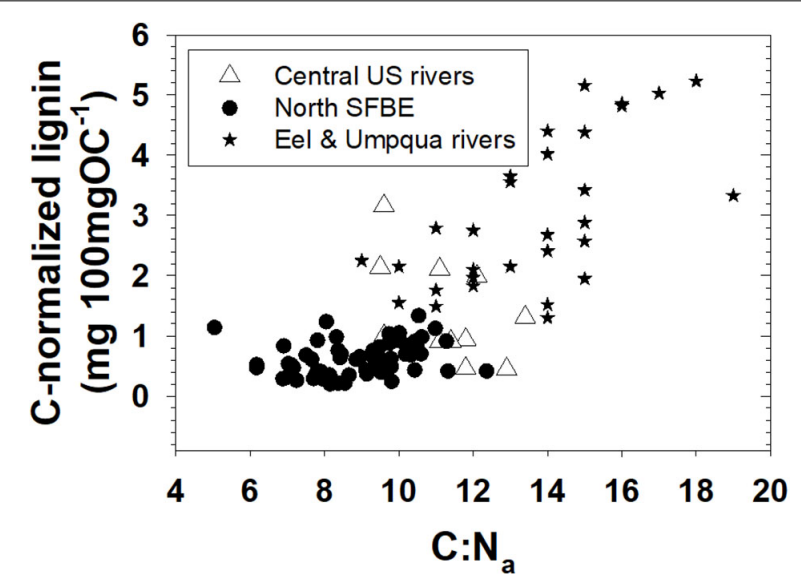

FIGURE 5 | Carbon-normalized lignin yields, $\Lambda_{8}$, vs. atomic ratio of carbon to nitrogen, $\mathrm{C}: \mathrm{N}_{\mathrm{a}}$, for this study in comparison to a survey of rivers across the US (Onstad et al., 2000) and the Eel and Umpqua rivers (Goñi et al., 2013) as comparative rivers to the Sacramento River headwaters. through the lower food web (Howe and Simenstad, 2011). The latter study suggests that wetland detrital material is more than just a carbon source for respiration. Of great interest is the chemical composition of detrital material and whether or not there are compositional clues in POM beyond chlorophyll that would indicate greater or lesser value as a food source.

Lignin biomarkers can provide information about the food value of vascular plant tissues in multiple ways. Plots of syringyl to vanillyl phenols $(\mathrm{S}: \mathrm{V})$ vs. cinnamyl to vanillyl phenols $(\mathrm{C}: \mathrm{V})$ are often used to assign relative source contributions of different plant types and tissues to sample OM (e.g., Hedges and Mann, 1979; see color shaded boxes in Figure 6A). However, proximity to prominent source tissues in $\mathrm{S}: \mathrm{V}$ vs. C:V space can also indicate fresher (nearer the source signatures) vs. more degraded (farther from the source signatures) for prominent plant sources in the Delta. Tule has previously been identified as a potentially important source of vascular plant carbon for the lower food web (Harfmann et al., 2019), but another prominent Delta wetland

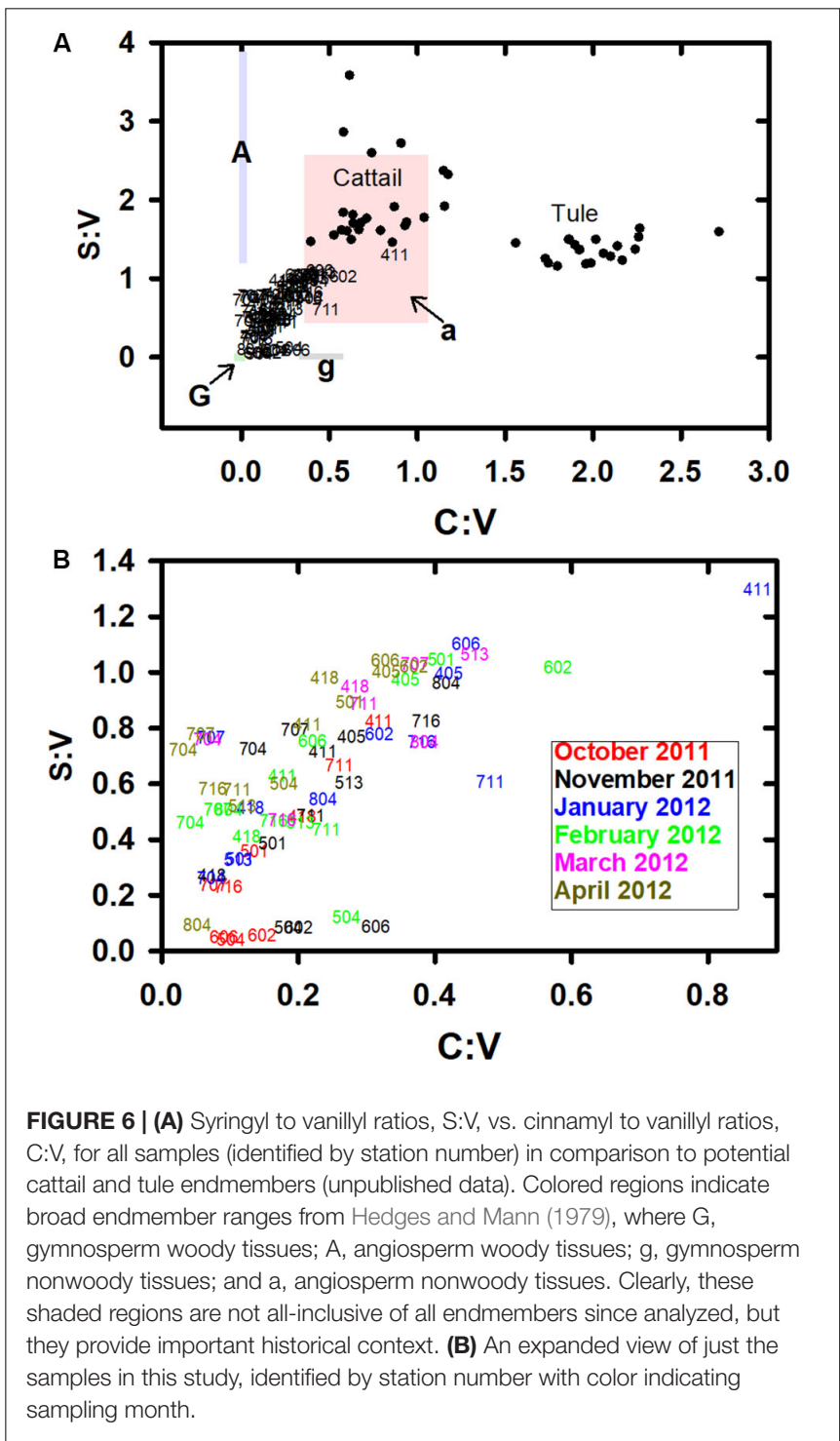


plant is cattail. When these two plant materials (unpublished data) are included along with all the samples in $S: V$ vs. C:V space, it is striking that the samples most closely resemble the cattail signature (Figure 6A). This could be interpreted that cattail is more relevant in the water column than tule, but also prompts questions as to why the tule signal is not stronger, given the prevalence of tule in Delta wetlands. Overall, the relative relationships in Figure 6 highlight a hypothesis that samples with higher $\mathrm{S}: \mathrm{V}$ and $\mathrm{C}: \mathrm{V}$ ratios will be of better food quality because they contain a higher proportion of undegraded wetland vascular plant material. Notably, C:V values were statistically higher in the western stations than those in the eastern stations (Table 1), which in this system could most easily be derived from monocot sources such as tule and cattail.

Of the five months that were consistently sampled, January 2012 samples on average were most similar to the cattail signature, and October 2011 samples least (see Figure 6B for an expanded view of station data, with upper right values closest to the cattail source signature). Notably, nine of the closest 13 samples to the cattail signature are within the Suisun Marsh $(602,606)$ or in proximity to Suisun Bay $(405,411,501)$. This also corresponds to the earlier identified trend with higher carbon-normalized yields of lignin in the westernmost samples and suggests that the highest potential for incorporation of vascular plant materials into the lower food web is currently in the western Delta.

Another indicator of food quality is that of acid to aldehyde ratios for both vanillyl phenols, $(\mathrm{Ad}: \mathrm{Al}) \mathrm{v}$, and syringyl phenols, (Ad:Al)s, where the lowest values correspond to least degraded plant tissues (Hedges et al., 1988; Opsahl and Benner, 1995) and therefore presumably greater food quality. In our samples, there was limited distinction in $(\mathrm{Ad}: \mathrm{Al})$ s between sites and months; however, the average $(\mathrm{Ad}: \mathrm{Al}) \mathrm{v}$ at stations $711+716$ was higher than the average of all other stations ( 0.92 vs. 0.74 , two-tailed $t$-test assuming unequal variance, $p$-value $=0.0034)$. This is not a surprising finding, given that 711 and 716 are the entry points into the Delta of the Sacramento River, and therefore particulate lignin should reflect more degraded sources from agricultural soils with essentially no O-horizon. Stations further into the Delta can be overprinted by local, less degraded wetland sources.

Finally, the latter issue of overprinting-in particular the extent to which it occurs-is a key issue related to wetland restoration benefits to the lower food web. In other words, how much of the POM in the Delta is potentially wetland material available for consumption? One way of estimating this value is to compare carbon-normalized lignin yields, $\Lambda_{8}$, of incoming river POM with Delta POM downstream. Across the dataset, the $\Lambda_{8}$ values at station 711, the cleanest Sacramento River endmember, were consistently among the lowest values across all seasons. If we assume that all higher values in the Delta are a result of local landscape overprinting primarily from wetlands, then we can calculate a wetland contribution with appropriate wetland endmembers. However, wetland detrital material will have a different $\Lambda_{8}$ than mineral-bound OM due to multiple phase changes (solubilization followed by sorption) in the latter. The average $\Lambda_{8}$ for station 711 was $0.39 \mathrm{mg} 100 \mathrm{mgOC}^{-1}$. A representative $\Lambda_{8}$ for cattail and tule plant materials is $\sim 7 \mathrm{mg} 100 \mathrm{mgOC}^{-1}$, while the Mississippi River endmember estimated in the introduction of $\sim 2 \mathrm{mg} 100 \mathrm{mgOC}^{-1}$ is a reasonable representation of integrated mineral-bound vascular plant $\mathrm{OM}$ in a river. This approach can be demonstrated on a plot of $\Lambda_{8}$ vs. the calculated percentage of phytoplankton contributions to $\mathrm{OM}$, which allows a visualization of the riverine endmember and then calculated wetland contributions based on the two-endmember extremes (Figure 7). This exercise shows the potential for the highest lignin-enriched samples to be 50 $60 \%$ wetland if using the mineral-bound endmember and 13$15 \%$ if using the plant material endmember. In all likelihood, wetland OM contributes to Delta POM by both discrete detrital material and mineral-bound organics, and the true answer is probably in the middle. However, any phytoplankton contributions within the Delta will lower $\Lambda_{8}$ and lead to an underestimate. The key point is not the exact percentage but to demonstrate that there is a strong likelihood that increased wetland restoration can be expected to inject even more wetland OM into the POM pool.

\section{Algal Carbon Is Still a Primary Driver of Particulate Organic Carbon Dynamics}

In addition to previously described east/west trends in chlorophyll and carbon-normalized yields of lignin, elemental analyses of the particles revealed a weak $\left(r^{2}=\sim 0.3\right.$, depending on curve-fitting) but significant $(p<0.001)$ decrease in weight percent organic carbon on the particles with increasing salinity (Figure 8A). This is largely mirrored by chlorophyll (Figure 8B), and in fact, there is a strong correlation between chlorophyll on a mass/mass basis and wt.\% OC (Figure 8C). Chlorophyll can be scaled to POC using average $\mathrm{C}$ : $\mathrm{Chl}$ ratios, and using the same scaling factor of 35 as Canuel et al. (1995) indicates that phytoplankton accounted for 3-36\% (Figure 7; average 9\%) of

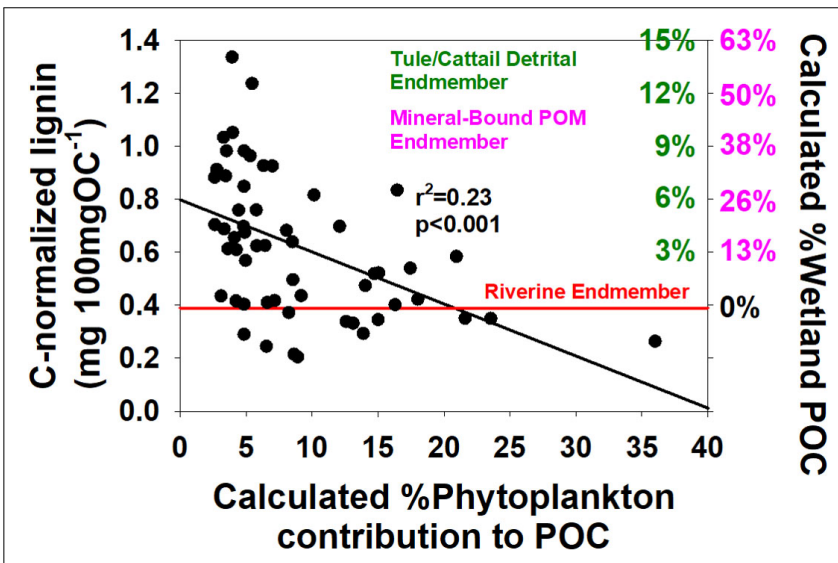

FIGURE 7 | Carbon-normalized lignin yields, $\Lambda_{8}$, vs. \%Phytoplankton-derived carbon, and \%wetland-derived materials calculated from a two-endmember mixing model. The red line represents the average $\Lambda_{8}$ for the Sacramento River endmember at station 711, green scale on the right represents tule/cattail senescent plant material as an endmember, while the pink represents a mineral-bound endmember as estimated from the Mississippi River. 
A
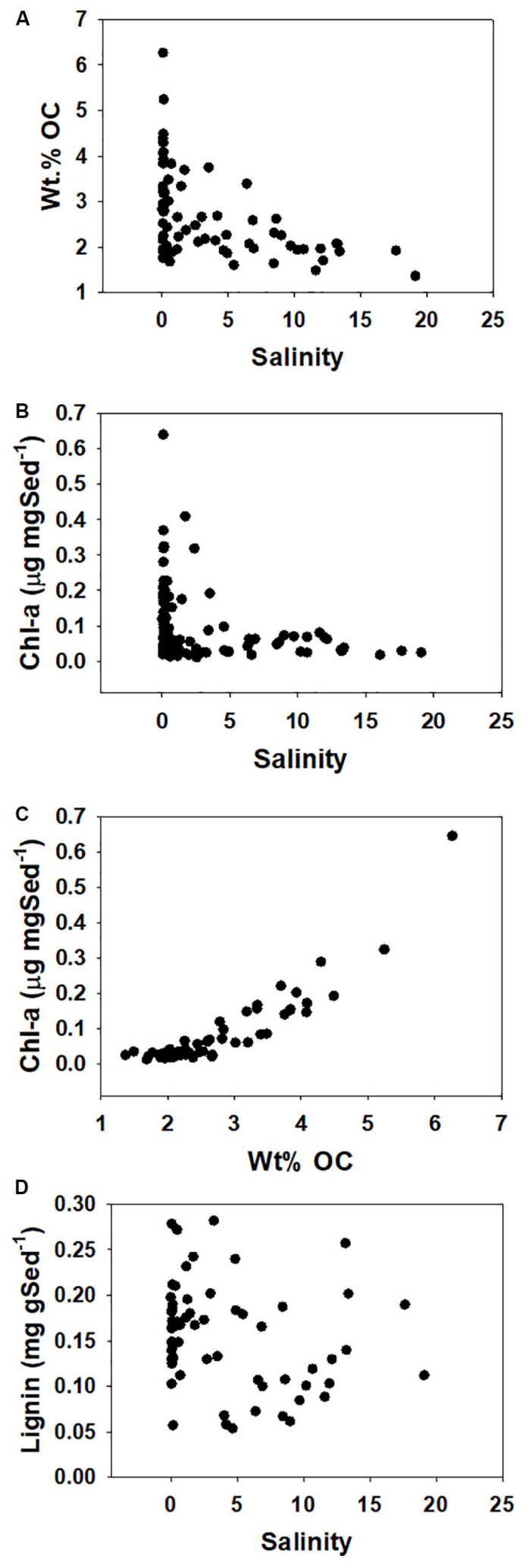

FIGURE 8 | (A) Weight percent OC vs. salinity for all samples.

(B) Chlorophyll-a as a sediment concentration vs. salinity. (C) Chlorophyll-a vs. weight percent organic carbon (OC). (D) Lignin as a sediment concentration vs. salinity. the POC sampled. In contrast to the chlorophyll, corresponding loadings of lignin on a particle mass basis show no trend with salinity (Figure 8D), suggesting that the decrease in carbon loading from low to high salinity waters is almost exclusively a result of degradation of algal biomass.

This is not a surprising result, as it is well-known that the lower food web is strongly reliant on algal sources and in a food-starved estuary such as the SFBE, it is expected that primary production will be nearly quantitatively consumed. In combination with the consistent lignin loadings across salinities, it would be tempting to conclude that vascular plant carbon is unimportant to the food web. However, this does not take into account differences in lignin composition that shows that vascular plant carbon in the more lignin-rich samples is less degraded (Figure 4) and therefore likely more available for selective consumption by copepods (e.g., Harfmann et al., 2019).

\section{Implications}

Change in environmental systems is well-documented, but it is easy to forget that it is relentless and often occurring faster than we realize. In some sense, our research is already outdated by the time it is published. In a system as heavily impacted directly by human activity-and now climate change-as the SFBE and Delta, the current state can be a moving target. This has significant ramifications for management efforts aimed at trying to recover and preserve ecological function and highlights the need for research funding priorities to include continued monitoring and experimentation, even on science that is not being hotly debated.

This dataset points toward shifting dynamics in the north SFBE, with changing particle compositions and spatial shifts from east to west that likely impact the lower food web. Lower chlorophyll in the Suisun Bay region in concert with higher vascular plant food quality suggests a greater reliance on nonalgal particles, which could become even more important in the future if the observed shift in this dataset is only the beginning. However, restored wetland in any region of the Delta has the potential for bolstering fish in near proximity (Howe and Simenstad, 2011), and although consensus appears to be that impacts will be local (Herbold et al., 2014), the selectivity of copepods toward wetland detrital material may warrant a reevaluation as to how far into open waters a wetland might confer food web benefits. Given the strong copepod selectivity specifically toward tule detrital material observed by Harfmann et al. (2019), it is worth exploring in more detail the lignin compositional relationship between north SFBE particles and the two dominant wetland endmembers, cattail and tule. Does the strong resemblance between north SFBE particles and cattail indicate lower food quality, or that tule is readily consumed and only the cattail signature remains?

Restoration outcomes can be improved by adaptively combining better scientific understanding of current conditions with overall project goals. Higher concentrations of tule wetlands in regions with lower primary production could be one strategy. But more importantly, there is a need for ongoing research into POC cycling in the SFBE to include changes that result from the restoration itself. 


\section{NOMENCLATURE}

\begin{tabular}{|c|c|}
\hline Abbreviation & Meaning \\
\hline$(\mathrm{Ad}: \mathrm{Al})_{v}$ & $\begin{array}{l}\text { Ratio of lignin vanillyl phenol acids to } \\
\text { aldehydes }\end{array}$ \\
\hline$(\mathrm{Ad}: \mathrm{Al}) \mathrm{s}$ & $\begin{array}{l}\text { Ratio of lignin syringyl phenol acids to } \\
\text { aldehydes }\end{array}$ \\
\hline TSS & Total suspended sediment \\
\hline $\mathrm{C}: \mathrm{V}$ & Ratio of cinnamyl to vanillyl lignin phenols \\
\hline DOC & Dissolved organic carbon \\
\hline POC & Particulate organic carbon \\
\hline $\mathrm{POM}$ & Particulate organic matter \\
\hline $\mathrm{OM}$ & Organic matter \\
\hline $\mathrm{PN}$ & Particulate nitrogen \\
\hline $\mathrm{Wt} \% \mathrm{OC}$ & Weight percent organic carbon \\
\hline Chl- $a$ & Chlorophyll $a$ \\
\hline $\mathrm{S}: \mathrm{V}$ & Ratio of syringyl to vanillyl lignin phenols \\
\hline$\sum_{8}$ & $\begin{array}{l}\text { Sum of eight particulate lignin phenol } \\
\text { concentrations }\end{array}$ \\
\hline$\Lambda_{8}$ & Lignin carbon normalized yields \\
\hline $\mathrm{C}: \mathrm{N}_{\mathrm{a}}$ & Atomic ratio of carbon to nitrogen \\
\hline PON & Particulate organic nitrogen \\
\hline \%Phyto-C & $\begin{array}{l}\text { Calculated percent of POC derived from live } \\
\text { phytoplankton }\end{array}$ \\
\hline
\end{tabular}

\section{DATA AVAILABILITY STATEMENT}

All datasets generated for this study are included in the article/Supplementary Material.

\section{REFERENCES}

Bergamaschi, B. A., Fleck, J. A., Downing, B. D., Boss, E., Pellerin, B., Ganju, N. K., et al. (2011). Methyl mercury dynamics in a tidal wetland quantified using in situ optical measurements. Limnol. Oceanogr. 56, 1355-1371. doi: 10.4319/lo.2011.56.4.1355

Bergamaschi, B. A., Fleck, J. A., Downing, B. D., Boss, E., Pellerin, B. A., Ganju, N. K., et al. (2012). Mercury dynamics in a San Francisco Estuary tidal wetland: assessing dynamics using in situ measurements. Estuar. Coasts 35, 1036-1048. doi: 10.1007/s12237-012-9501-3

Canuel, E. A., Cloern, J. E., Ringelberg, D. B., Guckert, J. B., and Rau, G. H. (1995). Molecular and isotopic tracers used to examine sources of organic matter and its incorporation into the food webs of San Francisco Bay. Limnol. Oceanogr. 40,67-81. doi: 10.4319/lo.1995.40.1.0067

Clesceri, L. S., Eaton, A. D., and Greenberg, A. E. (1998). Standard Methods for the Examination of Water and Wastewater. Washington, DC: American Public Health Association.

Cloern, J., Canuel, E., and Harris, D. (2002). Stable carbon and nitrogen isotope composition of aquatic and terrestrial plants of the San Francisco Bay estuarine system. Limnol. Oceanogr. 47, 713-729. doi: 10.4319/lo.2002.47.3. 0713

\section{AUTHOR CONTRIBUTIONS}

$\mathrm{PH}$ and $\mathrm{BB}$ conceived and designed the study and drafted and revised the manuscript. All authors acquired, analyzed or interpreted the data, investigated and resolved the accuracy of the study, and approved the final version of the manuscript.

\section{FUNDING}

This work was supported by funding from the Bureau of Reclamation to the USGS through Agreement \#R15PG00085 (BB) and the National Science Foundation grant OCE$1335622(\mathrm{PH})$.

\section{ACKNOWLEDGMENTS}

We gratefully acknowledge sample processing and analytical efforts by Daniel Jara and Hope Fisher.

\section{SUPPLEMENTARY MATERIAL}

The Supplementary Material for this article can be found online at: https://www.frontiersin.org/articles/10.3389/feart. 2020.00185/full\#supplementary-material

FIGURE S1 | Sacramento River hydrograph across the sampling period with red lines marking the approximate sampling times.

FIGURE S2 | A graphic showing the potential shift in POC C: $\mathrm{N}_{\mathrm{a}}$ with time in the northern SFBE. Data and corresponding citations are given in section "North San Francisco Bay Estuary Particulate Organic Carbon Now and Then”.

TABLE S1 | All data for all stations analyzed for lignin.

TABLE S2 | Month by month comparisons of significant differences using two-tailed $t$-test assuming unequal variance. Shaded cells represent $p$-values $<0.05$.

Cloern, J. E., Canuel, E., and Wienke, S. M. (1993). Particulate Organic Matter in the San Francisco Bay Estuary, California: Chemical Indicators of its Origin and Assimilation Into the Benthic Food Web. Menlo Park, CA: U.S. Geological Survey Open-File Report, 93-146.

Cloern, J. E., Foster, S. Q., and Kleckner, A. E. (2014). Phytoplankton primary production in the world's estuarine-coastal ecosystems. Biogeosciences 11, 24772501. doi: 10.5194/bg-11-2477-2014

Cohen, A., and Carlton, J. (1998). Accelerating invasion rate in a highly invaded estuary. Science 279, 555-558. doi: 10.1126/science.279.5350.555

Dahm, C. N., Parker, A. E., Adelson, A. E., Christman, M. A., and Bergamaschi, B. A. (2016). Nutrient dynamics of the Delta: effects on primary producers. San Franc. Estuary Watershed Sci. 14:4. doi: 10.15447/sfews.2016v14iss4art4

Deverel, S., and Rojstaczer, S. (1996). Subsidence of agricultural lands in the Sacramento San Joaquin Delta, California: role of aqueous and gaseous carbon fluxes. Water Resour. Res. 32, 2359-2367. doi: 10.1029/96WR01338

Eckard, R. S., Bergamaschi, B. A., Pellerin, B. A., Spencer, R. G. M., Dyda, R. Y., and Hernes, P. J. (2020). Organic matter integration, overprinting, and the relative fraction of optically active organic carbon in a human-impacted watershed. Front. Earth Sci. 8:67. doi: 10.3389/feart.2020.00067

Eckard, R. S., Hernes, P. J., Bergamaschi, B. A., Stepanauskas, R., and Kendall, C. (2007). Landscape scale controls on the vascular plant component of dissolved 
organic carbon across a freshwater delta. Geochim. Cosmochim. Acta 71, 59685984. doi: 10.1016/j.gca.2007.09.027

San Francisco Bay Area Wetlands Ecosystem Goals Project (2015). The Baylands and Climate Change: What We Can Do. Baylands Ecosystem Habitat Goals Science Update 2015. Oakland, CA: Prepared by the San Francisco Bay Area Wetlands Ecosystem Goals Project.

Goñi, M. A., Hatten, J. A., Wheatcroft, R. A., and Borgeld, J. C. (2013). Particulate organic matter export by two contrasting small mountainous rivers from the Pacific Northwest, U.S.A. J. Geophys. Res. Biogeosci. 118, 112-134. doi: 10.1002/ jgrg.20024

Harfmann, J., Kurobe, T., Bergamaschi, B., Teh, S., and Hernes, P. (2019). Plant detritus is selectively consumed by estuarine copepods and can augment their survival. Sci. Rep. 9:9076. doi: 10.1038/s41598-019-45503-6

Hedges, J. I., Blanchette, R. A., Weliky, K., and Devol, A. H. (1988). Effects of fungal degradation on the $\mathrm{CuO}$ oxidation products of lignin: a controlled laboratory study. Geochim. Cosmochim. Acta 52, 2717-2726. doi: 10.1016/0016-7037(88) 90040-3

Hedges, J. I., and Mann, D. C. (1979). Characterization of plant tissues by their lignin oxidation products. Geochim. Cosmochim. Acta 43, 1803-1807. doi: 10.1016/0016-7037(79)90028-0

Herbold, B., Baltz, D. M., Brown, L., Grossinger, R., Kimmerer, W., Lehman, P., et al. (2014). The role of tidal marsh restoration in fish management in the San Francisco estuary. San Franc. Estuary Watershed Sci. 12:1. doi: 10.15447/ sfews.2014v12iss1art1

Hernes, P. J., and Benner, R. (2002). Transport and diagenesis of dissolved and particulate terrigenous organic matter in the North Pacific Ocean. Deep-Sea Res. Part-Oceanogr. Res. Pap. 49, 2119-2132. doi: 10.1016/s0967-0637(02)00128-0

Hernes, P. J., Dyda, R. Y., and McDowell, W. H. (2017a). Connecting tropical river DOM and POM to the landscape with lignin. Geochim. Cosmochim. Acta 219, 143-159. doi: 10.1016/j.gca.2017.09.028

Hernes, P. J., Kaiser, K., Dyda, R. Y., and Cerli, C. (2013a). Molecular trickery in soil organic matter: hidden lignin. Environ. Sci. Technol. 47, 9077-9085. doi: 10.1021/es401019n

Hernes, P. J., Robinson, A. C., and Aufdenkampe, A. K. (2007). Fractionation of lignin during leaching and sorption and implications for organic matter “freshness.". Geophys. Res. Lett. 34:L17401. doi: 10.1029/2007GL031017

Hernes, P. J., Spencer, R. G. M., Dyda, R. Y., O’Geen, A. T., and Dahlgren, R. A. (2017b). The genesis and exodus of vascular plant DOM from an oak woodland landscape. Front. Earth Sci. 5:9. doi: 10.3389/feart.2017.00009

Hernes, P. J., Spencer, R. G. M., Dyda, R. Y., Pellerin, B. A., Bachand, P. A. M., and Bergamaschi, B. A. (2013b). DOM composition in an agricultural watershed: assessing patterns and variability in the context of spatial scales. Geochim. Cosmochim. Acta 121, 599-610. doi: 10.1016/j.gca.2013.07.039

Howe, E. R., and Simenstad, C. A. (2011). Isotopic determination of food web origins in restoring and ancient estuarine Wetlands of the San Francisco Bay and Delta. Estuar. Coasts 34, 597-617. doi: 10.1007/s12237-011-9376-8

Jassby, A., and Cloern, J. (2000). Organic matter sources and rehabilitation of the Sacramento-San Joaquin Delta (California, USA). Aquat. Conserv. Mar. Freshw. Ecosyst. 10, 323-352. doi: 10.1002/1099-0755(200009/10)10:5<323:: AID-AQC417<3.0.CO;2-J

Kendall, C., Silva, S. R., and Kelly, V. J. (2001). Carbon and nitrogen isotopic compositions of particulate organic matter in four large river systems across the United States. Hydrol. Process. 15, 1301-1346. doi: 10.1002/hyp.216

Kurobe, T., Lehman, P. W., Hammock, B. G., Bolotaolo, M. B., Lesmeister, S., and Teh, S. J. (2018). Biodiversity of cyanobacteria and other aquatic microorganisms across a freshwater to brackish water gradient determined by shotgun metagenomic sequencing analysis in the San Francisco Estuary. USA. PLoS One 13:e203953. doi: 10.1371/journal.pone. 0203953

Lucas, L. (2010). "Implications of estuarine transport for water quality," in Contemporary Issues in Estuarine Physics, ed. A. Valle-Levinson (Cambridge University Press), 273-307. doi: 10.1017/cbo978051167 6567.011

Müller-Solger, A., Jassby, A., and Müller-Navarra, D. (2002). Nutritional quality of food resources for zooplankton (Daphnia) in a tidal freshwater system (Sacramento-San Joaquin River Delta). Limnol. Oceanogr. 47, 1468-1476. doi: 10.4319/lo.2002.47.5.1468

Murrell, M. C., and Hollibaugh, J. T. (2000). Distribution and composition of dissolved and particulate organic carbon in northern San Francisco Bay during low flow conditions. Estuar. Coast. Shelf Sci. 51, 75-90. doi: 10.1006/ecss.2000. 0639

Onstad, G. D., Canfield, D. E., Quay, P. D., and Hedges, J. I. (2000). Sources of particulate organic matter in rivers from the continental USA: lignin phenol and stable carbon isotope compositions. Geochim. Cosmochim. Acta 64, 3539-3546. doi: 10.1016/s0016-7037(00)00451-8

Opsahl, S., and Benner, R. (1995). Early diagenesis of vascular plant tissues: lignin and cutin decomposition and biogeochemical implications. Geochim. Cosmochim. Acta 59, 4889-4904. doi: 10.1016/0016-7037(95) 00348-7

San Francisco Estuary Institute-Aquatic Science Center [SFEI-ASC] (2014). A Delta Transformed: Ecological Functions, Spatial Metrics, and Landscape Change in the Sacramento-San Joaquin Delta. A Report of SFEI-ASC's Resilient Landscapes Program, Publication \#729. Richmond, CA: San Francisco Estuary Institute-Aquatic Sciences Center.

Sigleo, A. C., and Macko, S. A. (2002). Carbon and nitrogen isotopes in suspended particles and colloids, Chesapeake and San Francisco estuaries, U.S.A. Estuar. Coast. Shelf Sci. 54, 701-711. doi: 10.1006/ecss.2001.0853

Sobczak, W. V., Cloern, J. E., Jassby, A. D., Cole, B. E., Schraga, T. S., and Arnsberg, A. (2005). Detritus fuels ecosystem metabolism but not metazoan food webs in San Francisco estuary's freshwater Delta. Estuaries 28, 124-137. doi: $10.1007 /$ bf02732759

Spencer, R. G. M., Aiken, G. R., Dyda, R. Y., Butler, K. D., Bergamaschi, B. A., and Hernes, P. J. (2010). Comparison of XAD with other dissolved lignin isolation techniques and a compilation of analytical improvements for the analysis of lignin in aquatic settings. Org. Geochem. 41, 445-453. doi: 10.1016/j.orggeochem.2010.02.004

Disclaimer: Any use of trade, firm, or product names is for descriptive purposes only and does not imply endorsement by the U.S. Government.

Conflict of Interest: The authors declare that the research was conducted in the absence of any commercial or financial relationships that could be construed as a potential conflict of interest.

Copyright (c) 2020 Hernes, Dyda and Bergamaschi. This is an open-access article distributed under the terms of the Creative Commons Attribution License (CC BY). The use, distribution or reproduction in other forums is permitted, provided the original author(s) and the copyright owner(s) are credited and that the original publication in this journal is cited, in accordance with accepted academic practice. No use, distribution or reproduction is permitted which does not comply with these terms. 